\title{
Gender Matters. The Grand Architectural Revolution
}

\section{Dörte Kuhlmann, Guest-Editor}

For many of us, a new year is a promise of change or renewal, and 2020 is no exception. Every story in this issue reflects current and past social challenges in relation to gender for planners, sheds light on forgotten and current female pioneers, and last but not least it shows the power of architecture.

Looking at the global world in 2020 , we notice that high-rise buildings around the globe follow international architecture aspirations, that Apple, Google, Amazon, Otis elevators and Samsung climate control can basically be found everywhere. But instead of a global agreement on social issues, there are still tremendous differences between various cultures when it comes to gender issues. While some western countries wonder whether there are two or three biological sexes and perhaps more than the fiftyeight different genders of Facebook, other countries rule out anything beyond two sexes and condemn homosexuality or transgender of any kind with strict law enforcement and severe punishments, including death. Both positions are usually reflected by and linked to political discussions as well as religious issues. Given that freedom of speech is usually declared a core right of freedom and certainly true for so-called highly developed countries, it is surprising how emotional, harsh and anti-rational the different positions are current debate.

J.K. Rowling, the famous author of the Harry Potter books, recently sparked such a controversy with a Twitter post defending a researcher who was fired for "stating that sex is real." Rowling, a mother of three children, answered in support of Maya Forstater, a researcher who was fired after posting that a person cannot change their biological sex. "Dress however you please. Call yourself whatever you like. Sleep with any consenting 
adult who'll have you. Live your best life in peace and security. But force women out of their jobs for stating that sex is real? \#IStandWithMaya \#ThislsNotADrill," she posted.

What we learn is that sex matters and gender matters. We learn that freedom of speech is not necessarily freedom of opinion and that even talking about sex and gender means having to explore legal issues. What would be an appropriate response? If we take a careful and modest position, a somewhat poetic response could be as follows: "In these days of struggle and desire, who of us really understands how to live?" What could have been a follow up in the Twitter discussion of Rowling's statement was a query by Melusina Fay Peirce more than a century ago in the November 1868 issue of The Atlantic Monthly. The timeliness of that issue takes us back to the roots of the women's movement, to the suffragettes and to the female pioneers in planning. Of course, the gender discussion is comparably young and seems to be constantly moving or changing directions. While many people these days are aware that it was not until 1919 that women were first admitted to the technical universities in Europe or the United States and received the right to vote in many countries, albeit not always on the same equal footing as men, fewer people know that it was as late as 1971 that women in Switzerland officially received the right to vote, and even then not in every canton: for instance, it took as long as 1990 for women in the canton of Appenzell to receive the right to vote. Although most of the readers of this magazine may have a different personal experience, equal rights for men and women are certainly not a given natural condition in the so-called western democracies - instead, to be honest, they have had a rather short history.

Of course, the struggle for equal rights for men and women was the necessary theoretical framework to extend the concept of antidiscrimination and inclusion to further issues of race, class, religion or sexual orientation. When French post structuralism entered academia, the humanities and architecture were immediately faced by intense debates on diversity and the importance of social constructions. However, it soon became clear that in architecture not everything is a mere social construction; some constructions are particularly physical and have a strong social impact because of their physical rather than metaphysical existence. Authors like Leslie Kane Weisman, Dolores Hayden and Daphne Spain were pioneers in demonstrating the relation of gender roles, power and the built environment. Weisman reasoned that buildings and spatial organizations reflect and constitute gender, race and class relations in society as much as the syntax of language does and that they contribute to the dominance of one group over another, just as language does.

She supported this hypothesis by saying that architecture represents the material legacy of those who have the economic or political power to build. To that effect, architecture is said to be the product of social, political and economic factors whose values are established "in the forms themselves, the processes through which they are built, and the manner in which 
they are used." According to Weisman, "creating buildings involves moral choices that are subject to moral judgment." 1

Sexual differentiation is sometimes openly demonstrated, even in contemporary buildings, which contributes to the solidification of role images - and as such should absolutely be criticized for moral reasons. Spain argued in her 1992 book Gendered Spaces that buildings and architectural settings strengthen gender roles and systems of power and control. Similarly, in her 1981 book The Grand Domestic Revolution, Hayden provided numerous interesting examples of how women and female architects were able to contribute to the architectural discourse and help improve it. Also, in her 1980 essay "What Would a Non-Sexist City Be Like? Speculations on Housing, Urban Design, and Human Work" she reflected upon the difficulties in overcoming gender biases in city planning and related social problems. ${ }^{2}$ The key arguments are still valid today, forty years later. Political dimensions remain core factors for the success or failure of housing projects and equal opportunities for women and men alike. The western ideal image of housing (a single-family house with a large garden) has not really changed since the 1950s. Its suburban location is not suited for elderly people or those who do not own a car, because important infrastructure is missing. Land ownership is part of the problem, not only for economic but also ecological reasons. Housing, education and mobility expenses are constantly growing: the national debt has just surpassed twenty-three trillion dollars in the US while life for half of the families is as "liquid asset poor." Privately owned land makes it very difficult to start non-commercial, community based services and community infrastructure. Hayden concluded that a non-sexist city could only function in a non-sexist society that shares collective values and social responsibility.

This issue authors Claudia Mattogno and Chiara Belingardi pick up on Hayden's considerations and trace the visionary concepts of female planners from the early 1900s until today. By discussing various alternative design proposals for domestic work, they want to build gender genealogies, thus deepening contemporary requests for sharing and relationship spaces. The paper highlights the contribution of women as builders of social and physical spaces from late nineteenth century onwards and focuses on Italian movements of second and third generation feminists.

With its fast growing metropolises, Asia provides us with more radical examples of contemporary urban developments that may better anticipate future global strategies than one would find in the old and dense cities of Europe. Noemí Gómez Lobo, Yoshiharu Tsukamoto and Diego Martín Sánchez turn to Japan and discus the Tokyo city district of Jiyūgaoka as "women's realm." The transformation of this wealthy city district started in the 1970s, when multiple shops and services aimed at female customers started to flourish. The development of this district is tied to a special target group and gender model: the housewife as caretaker and consumer. 
This is astonishing because the early pioneers for feminist planning had explicitly tried to present new ways to overcome the role as housewife and consumer, as the Marxist August Bebel, one of the founders of the Social Democratic Party of Germany, who remarked in his famous 1883 book Women Under Socialism:

For millions of women, the private kitchen is one of the most exhausting, time-consuming and wasteful institutions in which they lose their health and good spirits, and which is an object of daily worries, especially when funds are very short-as is the case with most families. The private kitchen is just as backward and obsolete as the workshop of a small tradesman. Both mean the greatest inefficiency, a great waste of time, power, heating and lighting, food, etc." 3

It was for the same reason that some decades earlier (in 1825) William Thompson, together with Anna Wheeler, had addressed the American public, but actually "half of humanity", with the celebrated book Appeal to one half of the Human Race, Women, against the pretensions of the other half, Men, to retain them in Civil and Domestic Slavery. Thompson criticized the home as an "eternal prison for women" and an institution to make them ever more submissive. He therefore called for the economic independence of women: "To obtain equal rights, the basis of equal happiness with men, you must be 'respected' by them; not merely desired, like rare meats, to pamper their selfish appetites." ${ }^{4}$

In 1868 Melusina Fay "Zina" Pierce proposed a solution to this dilemma. The smart housewife in Cambridge, Massachusetts, organized women into producers' and consumers' cooperatives to perform domestic work collectively and charge their husbands retail prices equivalent to men's wages. Her position was that "educated women should seek to produce not with their hands but with their heads." To argue with the early feminists, female work power and expertise are human resources that a sustainable society has to include. Given that there are nowadays usually more than $50 \%$ female students in most architecture schools, it is surprising that female leaders in architecture firms are still rare. Liqun Bi, Barbara LaCost and Hengle Jiang point out in their article that females comprise only $10 \%$ of the leadership population at the 100 largest international firms in the US. Besides the question of additional work power and special expertise, why is diversity or female leadership desirable for companies and society? One further response can be found in the writings of Prussian Field-Marshal Helmuth Graf Von Moltke (1800-1891), a towering figure who helped define the federal German state with his military brilliance, and who came up with an interesting value matrix to categorize his officer corps. He stated that there were four categories of soldiers: 1. smart and energetic, 2. dumb and energetic, 3. smart and lazy, and 4. dumb and lazy. But who are the winners - who would be the best leader? While most people might suggest the 
intelligent and most athletic ones, Moltke decided differently. According to him, the smart and lazy ones would be the best commanders because they make the right thing happen but find the easiest way to accomplish the mission. The smart and energetic ones are best for general staff officers, because they create intelligent plans that make the right things happen. But their energy would be too exhaustive for the others. The dumb and lazy are best for simple jobs and follow orders without causing much harm. Only the dumb and energetic ones are dangerous and must be eliminated for they cause the wrong things to happen. The idea is that in the end military success is more a function of an army's ability to adjust more, which is also true for the success of a company. Hence, the right combination of different abilities, attitudes and perspectives helps to solve complex problems in the most efficient way. While Moltke focused only on men, the well-known pedagogue Friedrich Fröbel thought that women held the future of mankind in their hands because they form the first six decisive years of a child's life. He therefore demanded that every girl should be trained as an educator. He wrote: "It is characteristic for our time that we are stripping the female sex of its instinctive, passive role as a member of the human race and are elevating it to exactly the same authority as the male sex in terms of its character and its calling to cultivate humanity." ${ }^{5}$

Since the early 1920s, many female planners and designers emerged as professionals in the fields of architecture and interior design and helped to shape the architectural discourse. While some of them were well known during the lifetime or became renowned figures, such as Margarete Schütte-Lihotzky, others have more or less disappeared from history, despite their projects or famous networks. In her article "On the Work of Lisbeth Sachs," Stamatina Kousidi presents the forgotten female Swiss pioneer, while Paola Di Biagi reflects, in her contribution "The Role of Women in the Culture of Dwelling," upon Jacoba Mulder and Marjory Allen, Baroness of Hurtwood, two pioneering women planners and their impact on design and construction of domestic and urban spaces, with the aim of improving people's daily lives and social relations.

Still, architecture is full of historical terms, design concepts linked to traditional concepts of gender and power. Soumini Raja and Sumitra Nair examine in their article how the naming shapes and is shaped by the architecture and design practice within which it sits. In their article "No Architect Is an Island," Annelise Pitts and Julia Mandell address the issue whereby architectural professionals tend to describe their work in terms of personal agency rather than communality. Women often face significant bias as they embody the stereotypically agentic professional archetypes of the creative, but are also undervalued when they adopt more communally oriented professional personas. The authors propose strategies intended to improve professional outcomes by addressing the adverse effects of agency-orientation in architectural practice.

It seems to be tremendously difficult to overcome the gender bias in the architectural and design discourse. As Linda Nochlin pointed out in her 
famous article of 1971 "Why Have There Been No Great Women Artists?", the problem is an inherent problem of the discipline. As frequent co-authors and collaborators, women's stories often do not fit into conventional historical narratives of architectural production. Nevertheless, Nick Senske and Shelby Doyle dare to take a very optimistic position, arguing that the integration of digital tools into architectural design would offer a new space for more equally attributing contributions to the discipline.

Both hetero and gay male architects may claim famous Philip Johnson as their role model, but little is known about lesbian female architects. Hence the title of Olivier Vallerand's essay: "Where Are the Lesbian Architects? Visibility and Its Challenges." The lack of visibility of female planners is also discussed by Patrícia Santos Pedrosa who addresses the insufficient presence of women in the discourse by looking at Portugal as a case study.

Returning to the key question - Why does gender matter in architecture and design and what was the most important contribution of female practitioners to modern architecture? - was there such a contribution at all, one that we can directly relate to gender issues? The emphatic response is: Yes, indeed we can. Perhaps the whole modern movement took a particular turn because of the actions of women. Alice T. Friedman argued in her now famous book of 1998 Women and the Making of the Modern House that it took innovative female clients who inspired and supported famous architects to create the most important masterpieces of modernism. Kathleen James-Chakraborty reflects in her article "The Diversity of Women's Engagement with Modern Architecture and Design: Three Case Studies" on how modern architecture and design provided women with possibilities for transforming historically gendered activities into professional opportunities. She shows how women fostered design innovation by editing publications for a large, mostly female audience, by running businesses to sell design and establishing educational institutions. Ethel Power edited the magazine House Beautiful from 1923 till 1934, while Estrid Ericson established the Swedish design shop Svensk Tenn in 1924, and Gira Sarabhai founded first the Calico Museum and later the National Academy of Design, both in Ahmedabad, India.

We may also think of Ada Louise Huxtable, the first full-time architecture critic at a US newspaper when she joined The New York Times and who pioneered modern architectural criticism. Huxtable established architecture and urban design journalism in North America and contributed to raising public awareness of the urban environment. Similarly, Hélène de Mandrot, herself an artist and Swiss patron of modern art and architecture, part initiated and sponsored the foundational meeting of the Congrès Internationaux d'Architecture Moderne (CIAM) in June 1928 at her château in La Sarraz, Switzerland. Le Corbusier was aware that women would play a major role in promoting the new style and therefore he traveled the US giving lectures in department stores to housewives, to spread the word on the International Style. It was clear that his target group had to be primarily 
women who would hopefully demand new single-family houses for their own, featuring the latest architectural features. In fact, magazines such as House Beautiful or the Ladies Home Journal were not only important media for promoting architects like Frank Lloyd Wright to a wider audience and spreading their fame, but also served as catalysts for new ideas in architecture and design. The revolution of the modern style might have failed without the strong female support. We may conclude that gender matters - having a huge impact in numerous ways on the architectural discourse as we know it and sponsoring many important ideas that are captured in our most precious masterpieces.

\section{Notes}

1. Leslie Kane Weisman, Discrimination by Design: A Feminist Critique of the Man-Made Environment (Urbana IL, USA: University of Illinois Press, 1992), 2.

2. Dolores Hayden, "What Would a Non-Sexist City Be Like? Speculations on Housing, Urban Design, and Human Work," Signs 5, no. 3, supplement "Women and the American City" (Spring, 1980), 170-87 (supplement).

3. August Bebel, Die Frau und der Sozialismus (Bonn, Ger.: Dietz, 1985 - reprint of the anniversary edition of 1929), 418. See also Dolores Hayden, Redesigning the American Dream. Gender, Housing, and Family Life (New York: W.W. Norton \& Company, 2002), 88. 4. William Thompson and Anna Wheeler, Appeal of One Half the Human Race, Women, Against the Pretensions of the Other Half, Men, To Retain Them in Political and Thence in Civil and Domestic Slavery; In Reply to a Paragraph of Mr. Mill's Celebrated "Article On Government" (London: Richard Taylor, 1825). Reprinted in Marie Mulvey Roberts and Tamae Mizuta, eds., The Reformers: Socialist Feminism (London: Routledge and Thoemmes Press, 1995), 187-92, 196-202.

5. Friedrich Fröbel, as cited in M.I. Fassmann, "Die Mutter der Volksküchen," in Christiane Eifert and Susanne Rouette (eds.), Unter allen Umständen. Frauengeschichte(n) in Berlin (Berlin: Rotation, 1986), p. 39.

Dörte Kuhlmann is a Professor at the Institute of Bulding Research and Architectural History at Vienna University of Technology. Her research centers on iconology in architecture with a special focus on gender. She has also taught at Bauhaus University Weimar, UBT Prishtina and UIC Chicago. Her books include Building Gender (2002), Building Power (2003), Wood with a Difference (2009), Emotion in Architecture (2011), Wooden Boxes (2011), Gender Studies in Architecture: Space, Power and Difference (2013), The Art of (Re)creation (2014). She is member of the Editorial Board of Datutop. She has curated numerous exhibitions and focuses at present on user preferences and iconological aspects of architecture in school design. E-mail: doerte.kuhlmann@tuwien.ac.at 